Vol.3 No.1 Hal. $85-91$

Juni 2020

\title{
Unmet Need Keluarga Berencana Di Provinsi Kepulauan Riau Berdasarkan Data SDKI 2017
}

\author{
Risqi Utami ${ }^{(1)}$, Nurhafizah Nasution ${ }^{(2)}$ \\ Departement of Midwife ${ }^{(1)}$, Departement of Nursing ${ }^{(2)}$, Faculty of Medicine Batam University Indonesia
}

\author{
Risqi0512@univbatam.ac.id, nurhafizah.nst@univbatam.ac.id
}

\begin{abstract}
ABSTRAK
Salah satu indikator kurang berhasilnya program kependudukan (keluarga berencana) ialah masih terdapatnya kebutuhan keluarga berencana yang tidak terpenuhi (unmet need). Unmet need berpengaruh terhadap peningkatan jumlah penduduk yang masih menjadi salah satu permasalahan penduduk yang cukup berat, selain itu juga berdampak pada masalah kesehatan. Dampak yang ditimbulkan adalah peningkatan angka kematian ibu. Unmet need merupakan salah satu faktor penyebab $75 \%$ kematian ibu di Indonesia dan juga di dunia. Penelitian ini merupakan penelitian deskripsi dengan pendekatan kuantitatif dengan menggunakan data sekunder dari SDKI 2017. Populasi adalah WUS dengan sampel yang berjumlah 1073 responden. Hasil penelitian terdapat hubungan antara unmet need dengan umur ( $\mathrm{pValue}=0,00<0,05$ ), daerah tempat tinggal ( $\mathrm{p}$ Value $=0,02<0,05)$, tingkat pendidikan $(\mathrm{pValue}=0,00<0,05)$. Tidak ada hubungan antara unmet need dengan kuintil kekayaan (pValue=0,14>0,05). Rekomendasi penelitian diharapkan agar setiap kabupaten dan kota memiliki PL KB sehingga dapat memberikan KIE tentang KB lebih merata dan menyeluruh.
\end{abstract}

Kata Kunci : Unmet need, Umur, Pendidikan, tempat tinggal, kuintil kekayaan

\begin{abstract}
One indicator of the lack of success of the population program (family planning) is that there are still unmet need for family planning. Unmet need has an effect on increasing the number of population which is still one of the most severe population problems, but it also has an impact on health problems. The impact is an increase in maternal mortality. Unmet need is one of the factors causing $75 \%$ of maternal deaths in Indonesia and also in the world. This research is a descriptive study with a quantitative approach using secondary data from the 2017 IDHS. The population is WUS with a sample of 1073 respondents. The results of the study there is a relationship between unmet need with age ( $\mathrm{pValue}=0.00<0.05)$, area of residence $(\mathrm{p}$ Value $=0.02<0.05)$, level of education ( $\mathrm{pValue}=0.00<0.05)$. There is no relationship between unmet need and wealth quintile $(\mathrm{pValue}=0.14>0.05)$. Research recommendations are expected that each district and city has a family planning program so that they can provide IEC about family planning more evenly and comprehensively..
\end{abstract}

Keywords : Unmet need, Age, Education, residence, wealth quintile

\section{PENDAHULUAN}

\section{Latar Belakang}

Jumlah penduduk yang terus meningkat merupakan masalah besar bagi negara di dunia khususnya negara berkembang. Indonesia merupakan negara dengan jumlah penduduk terbesar keempat setelah Cina, India dan Amerika Serikat dengan laju pertumbuhan yang masih relatif tinggi. Pertumbuhan penduduk yang tinggi akan menghambat laju pembangunan di berbagai bidang, oleh karena itu upaya untuk menurunkan tingkat kelahiran perlu ditingkatkan. Tingginya pertumbuhan penduduk ini dapat diatasi salah satunya dengan pengaturan kehamilan dengan program Keluarga Berencana (KB). Menurut UndangUndang No.52 Tahun 2009 tentang perkembangan kependudukan dan pembangunan keluarga pasal 1, Keluarga berencana (KB) adalah upaya mengatur kelahiran anak, jarak, dan usia ideal melahirkan, mengatur kehamilan, melalui promosi, perlindungan, dan bantuan sesuai dengan hak reproduksi untuk mewujudkan keluarga yang berkualitas. Program KB di Indonesia telah diakui secara nasional dan internasional sebagai salah satu program yang 
telah berhasil menurunkan angka fertilitas secara nyata. Angka TFR Provinsi Kepulauan Riau mengalami penurunan angka dari 2,6 anak per wanita pada SDKI 2012 menjadi 2,3 per wanita pada' SDKI 2017. Namun bukan berarti masalah kependudukan di Indonesia selesai, akan tetapi program tersebut diupayakan tetap dipertahankan. Salah satu indikator kurang berhasilnya program kependudukan (keluarga berencana) ialah masih terdapatnya kebutuhan keluarga berencana yang tidak terpenuhi atau yang disebut dengan Unmet need KB. (Lystianingsih, 2016) . Unmet need KB didefinisikan sebagai persentase perempuan usia subur yang tidak menggunakan kontrasepsi, tetapi tidak menginginkan anak lagi atau ingin menjarangkan kehamilan (Bradley et al, 2012). Unmet need menjadi bahasan yang sangat penting dalam keluarga berencana. Unmet need KB menurut Markippudin (2011) dapat diartikan sebagai tidak terpenuhinya hak reproduksi perempuan karena ketidakmampuan menggunakan alat kontrasepsi. Unmet need berpengaruh terhadap peningkatan jumlah penduduk yang masih menjadi salah satu permasalahan penduduk yang cukup berat untuk diselesaikan di Indonesia. Selain dari kepadatan penduduk, unmet need juga berdampak pada masalah kesehatan. Dampak yang ditimbulkan dari unmet need $\mathrm{KB}$ adalah peningkatan angka kematian ibu (SDKI, 2012). Unmet need merupakan salah satu faktor penyebab $75 \%$ kematian ibu di Indonesia dan juga di dunia (Sariyati, 2014). Menurut penelitian (Lekshmi A.R dkk, 2014) di Karnataka, India unmet need dipengaruhi oleh faktor usia dan jumlah anak. Umur, pendapatan, kegagalan alat kontrasepsi sebelumnya, jumlah anak berpengaruh terhadap unmet need (Usman dkk, 2013). Menurut beberapa penelitian lainnya, pengetahuan, pendidikan, status penggunaan $\mathrm{KB}$, persetujuan suami, imformasi dari tenaga kesehatan tentang KB berpengaruh terhadap kejadian unmet need (Suseno, 2011; Utami dkk, 2013; Ulsafitri dan Fastin, 2015). Menurut Penelitian (Fadhila dkk, 2015) hanya dukungan suami yang mempengaruhi kejadian Unmet need sedangkan menurut penelitian (Fahrunnisa dan Meilinda, 2015) unmet need di pengaruhi oleh budaya, agama, larangan suami, keinginan jenis kelamin dan rumor negatif tentang $\mathrm{KB}$ yang mempengaruhi. Persentase unmet need meningkat seiring dengan bertambahnya usia dari wanita subur (BKKBN, 2016). Hal ini didasari oleh wanita di usia yang matang telah mencapai jumlah anak yang diinginkan dan berpikir bahwa sudah tidak memiliki kemungkinan untuk hamil di akhir masa reproduksinya. Oleh karena itu unmet need terjadi lebih besar pada wanita di usia matang dan meningkatkan risiko kehamilan yang tidak diinginkan (BKKBN,2016). Mengingat pengaruhnya terhadap indikator lain, penanganan terhadap kasus Unmet need $\mathrm{KB}$ harus lebih diperhatikan. Masih tingginya angka Unmet need KB di Indonesia merupakan masalah bagi pemerintah untuk mengendalikan pertumbuhan penduduk. Berdasarkan SDKI tahun 2012 angka Unmet need Provinsi Kepulauan Riau adalah 8\% dan terjadi peningkatan pada SDKI 2017 menjadi 10\%. Beberapa faktor yang mempengaruhi Unmet need KB yaitu umur, paritas, pendidikan, pengetahuan, alat kontrasepsi yang pernah digunakan, daerah tempat tinggal, kuntil kekayaan, biaya $\mathrm{KB}$, dukungan suami, dan pengambilan keputusan tentang keluarga berencana. Oleh karena itu dalam membantu BKKBN menurunkan Unmet Need KB sesuai target pemerintah diperlukan penelitian yang memperhatikan karakteristik Unmet Need dari faktor demografi, sosial dan ekonomi. Pada penelitian ini, akan dideskripiskan faktor yang Mempengaruhi Unmet Need KB di Provinsi Kepulauan Riau berdasarkan karakteristik faktor tersebut sehingga dapat dijadikan acuan untuk BKKBN dalam melakukan evaluasi kinerja memperhatikan faktor-faktor yang mendukung untuk ketercapaian target Unmet Need KB.

\section{METODE PENELITIAN}

Desain penelitian deskriptif korelatif dengan pendekatan retrospektif untuk mengetahui fenomena yang terjadi berdasarkan data yang sudah ada. Populasi dalam penelitian ini adalah Wanita Usia Subur dengan Jumlah Sampel dalam Penelitian ini adalah 1073 orang. 
Penelitian ini dilaksanakan di Provinsi kepulauan Riau. Waktu penelitian dilaksanakan pada bulan April 2019. Data yang digunakan dalam penelitian ini adalah data sekunder dari Hasil SDKI 2017.

\section{Analisis Model Struktural (inner Model)}

Analisis model structural atau (inner model) bertujuan untuk menguji hipotesis penelitian. Bagian yang perlu dianalisis dalam model structural yakni, koefisien determinasi (R Square) dengan pengujian hipotesis. Nilai yang digunakan untuk menganalisisnya adalah dengan melihat nilai Variance Inflation Factor (VIF). (Hair, Hult, Ringle, \& Sarstedt, 2014; Garson, 2016).Jika nilai VIF lebih besar dari 5,00 maka berarti terjadi masalah kolinearitas, dan sebaliknyatidak terjadi masalah kolinearitas jika nilai VIF $<5,00$ (Hair, Hult, Ringle, \& Sarstedt, 2014).

\section{HASIL DAN PEMBAHASAN}

ANALISA UNIVARIAT

Tabel 01. Distribusi Frekuensi berdasarkan umur

\begin{tabular}{|c|c|c|c|c|c|}
\hline \multicolumn{6}{|c|}{ Age in 5-year groups } \\
\hline & & Frequency & Percent & Valid Percent & $\begin{array}{c}\text { Cumulative } \\
\text { Percent }\end{array}$ \\
\hline \multirow[t]{8}{*}{ Valid } & $15-19$ & 142 & 13.2 & 13.2 & 13.2 \\
\hline & $20-24$ & 154 & 14.4 & 14.4 & 27.6 \\
\hline & $25-29$ & 156 & 14.5 & 14.5 & 42.1 \\
\hline & $30-34$ & 152 & 14.2 & 14.2 & 56.3 \\
\hline & $35-39$ & 179 & 16.7 & 16.7 & 73.0 \\
\hline & $40-44$ & 168 & 15.7 & 15.7 & 88.6 \\
\hline & $45-49$ & 122 & 11.4 & 11.4 & 100.0 \\
\hline & Total & 1073 & 100.0 & 100.0 & \\
\hline
\end{tabular}

Tabel 01 menunjukkan bahwa sebaran kelompok umur responden dengan presentase tertinggi adalah kelompok umur 35-39 tahun sebesar 179 orang ( 16,7 \%), dan pada umur 40-44 tahun sebesar 168 orang (15,7\%) sedangkan sebaran dengan kelompok umur terendah responden adalah kelompok umur 45-49 sebesar 122 orang $(11,4 \%)$.

Tabel 02 Distribusi Frekuensi berdasarkan tempat tinggal

Type of place of residence

\begin{tabular}{|ll|r|r|r|r|}
\hline & & Frequency & Percent & Valid Percent & $\begin{array}{c}\text { Cumulative } \\
\text { Percent }\end{array}$ \\
\hline Valid & Urban & 981 & 91.4 & 91.4 & 91.4 \\
& Rural & 92 & 8.6 & 8.6 & 100.0 \\
& Total & 1073 & 100.0 & 100.0 & \\
\hline
\end{tabular}

Tabel 02 menunjukkan bahwa sebagian besar responden tinggal di daerah perkotaan yaitu 981 orang $(91,4 \%)$, sedangkan sebaran responden yang tinggal di pedesan yaitu 92 orang $(8,6 \%)$. Banyaknya sebaran responden yang tinggal di perkotaan dari pada di pedesaan mempersepsikan bahwa daerah tempat tinggal memberikan arti tersendiri bagi masyarakat. Setiap masyarakat menginginkan tinggal di daerah yang banyak memiliki fasilitas baik itu fasilitas pendidikan, kesehatan, industri dan lain sebagainya. Provinsi Kepulauan Riau merupakan provinsi yang persebaran penduduknya tidak merata, dan cenderung terpusat di wilayah perkotaan, di daerah perkotaan mayarakat berlomba-lomba untuk meningkatkan perekonomian dan status sosial,sehingga menyebabkan keinginan membatasi kelahiran tinggi namun kesadaran untuk menggunakan alat/cara kontrasepsi sedikit sehingga perempuan unmet need di wilayah perkotaan lebih tinggi dari pada di pedesaan. 
Utami R, Nasution N : Unmet Need Keluarga Berencana di Provinsi Kepulauan Riau Berdasarkan Data SDKI 2017

Tabel 03 Distribusi Frekuensi berdasarkan pendidikan

Highest educational level

\begin{tabular}{|ll|r|r|r|r|}
\hline & Frequency & Percent & Valid Percent & $\begin{array}{c}\text { Cumulative } \\
\text { Percent }\end{array}$ \\
\hline Valid & No education & 8 & .7 & .7 & .7 \\
& Primary & 164 & 15.3 & 15.3 & 16.0 \\
& Secondary & 701 & 65.3 & 65.3 & 81.4 \\
Higher & 200 & 18.6 & 18.6 & 100.0 \\
Total & 1073 & 100.0 & 100.0 & \\
\hline
\end{tabular}

Tabel 03 menunjukkan bahwa tingkat pendidikan responden yang terbayak adalah Secondary yaitu 701 orang $(65,3 \%)$, sedangkan yang terendah adalah pada responden No education / tidak Sekolah sebanyak 8 orang $(0,7 \%)$. Tingkat pendidikan merupakan dasar pengembangan daya nalar seseorang dan jalan untuk memudahkan seseorang untuk menerima motivasi. Pendidikan dikategorikan rendah bila hanya sampai pada tingkat SMP dan dikategorikan tinggi apabila sampai pada tingkat SMA dan seterusnya (Ngatimin dalam Sumaila, 2011 dalam Nahlony 2017). Pendidikan wanita memiliki efek terhadap fertilitas. Wanita yang berpartisipasi lebih lama dalam pendidikan akan mengarah pada penundaan memiliki anak (Blossfeld \& Huinink, 1991).

Tabel 04 Distribusi Frekuensi berdasarkan kuintal kekayaan

Wealth index combinec

\begin{tabular}{|ll|r|r|r|r|}
\hline & Frequency & Percent & Valid Percent & $\begin{array}{c}\text { Cumulative } \\
\text { Percent }\end{array}$ \\
\hline Valid & Poorest & 48 & 4.5 & 4.5 & 4.5 \\
& Poorer & 103 & 9.6 & 9.6 & 14.1 \\
Middle & 226 & 21.1 & 21.1 & 35.1 \\
Richer & 295 & 27.5 & 27.5 & 62.6 \\
Richest & 401 & 37.4 & 37.4 & 100.0 \\
Total & 1073 & 100.0 & 100.0 & \\
\hline
\end{tabular}

Dilihat dari variabel indeks kekayaan. Dalam SDKI, indeks kekayaan terbagi menjadi lima bagian yaitu miskin, menengah, menengah bawah, menengah atas, teratas. Persentase terbesar pada wanita dengan status ekonomi teratas yaitu $401(37,4 \%)$.

Tabel 05. Distribusi Frekuensi Unmeed need

\begin{tabular}{|c|c|c|c|c|c|}
\hline \multicolumn{6}{|c|}{ Unmet need } \\
\hline & & Frequency & Percent & Valid Percent & $\begin{array}{c}\text { Cumulative } \\
\text { Percent }\end{array}$ \\
\hline \multirow[t]{11}{*}{ Valid } & Never had sex & 289 & 26.9 & 26.9 & 26.9 \\
\hline & Unmet need for spacing & 26 & 2.4 & 2.4 & 29.4 \\
\hline & Unmet need for limiting & 36 & 3.4 & 3.4 & 32.7 \\
\hline & Using for spacing & 127 & 11.8 & 11.8 & 44.5 \\
\hline & Using for limiting & 278 & 25.9 & 25.9 & 70.5 \\
\hline & Spacing failure & 6 & .6 & .6 & 71.0 \\
\hline & No unmet need & 120 & 11.2 & 11.2 & 82.2 \\
\hline & $\begin{array}{l}\text { Not married and no sex in } \\
\text { last } 30 \text { days }\end{array}$ & 36 & 3.4 & 3.4 & 85.6 \\
\hline & Infecund, menopausal & 153 & 14.3 & 14.3 & 99.8 \\
\hline & 99 & 2 & .2 & .2 & 100.0 \\
\hline & Total & 1073 & 100.0 & 100.0 & \\
\hline
\end{tabular}

Berdasarkan hasil analisis diperoleh responden unmed need kepri yang kebutuhan ber-KB nya yang tidak terpenuhi untuk menjarangkan kelahiran berjumlah $2.4 \%$ dan yang tidak terpenuhi untuk membatasi kelahiran berjumlah $3.4 \%$. 
ANALISA BIVARIAT

Tabel 06. Hubungan Umur dengan Unmet Need

\begin{tabular}{|c|c|c|c|c|c|c|c|c|c|c|}
\hline & & & \multirow{2}{*}{\multicolumn{7}{|c|}{ Age in 5-year groups }} & \multirow[b]{2}{*}{ Total } \\
\hline & & & $15-19$ & $20-24$ & $\frac{49-29}{25}$ & $30-34$ & & & $45-49$ & \\
\hline \multirow[t]{40}{*}{ Unmet need } & \multirow[t]{4}{*}{ Never had sex } & Count & 136 & 96 & 41 & 8 & 4 & 3 & 1 & 289 \\
\hline & & $\%$ within Unmet need & $47.1 \%$ & $33.2 \%$ & $14.2 \%$ & $2.8 \%$ & $1.4 \%$ & $1.0 \%$ & $0.3 \%$ & $100.0 \%$ \\
\hline & & $\begin{array}{l}\text { \% within Age in 5-year } \\
\text { groups }\end{array}$ & $95.8 \%$ & $62.3 \%$ & $26.3 \%$ & $5.3 \%$ & $2.2 \%$ & $1.8 \%$ & $0.8 \%$ & $26.9 \%$ \\
\hline & & $\%$ of Total & $12.7 \%$ & $8.9 \%$ & $3.8 \%$ & $0.7 \%$ & $0.4 \%$ & $0.3 \%$ & $0.1 \%$ & $26.9 \%$ \\
\hline & \multirow[t]{4}{*}{ Unmet need for spacing } & Count & 1 & 3 & 10 & 8 & 2 & 2 & 0 & 26 \\
\hline & & \% within Unmet need & $3.8 \%$ & $11.5 \%$ & $38.5 \%$ & $30.8 \%$ & $7.7 \%$ & $7.7 \%$ & $0.0 \%$ & $100.0 \%$ \\
\hline & & $\begin{array}{l}\text { \% within Age in 5-year } \\
\text { groups }\end{array}$ & $0.7 \%$ & $1.9 \%$ & $6.4 \%$ & $5.3 \%$ & $1.1 \%$ & $1.2 \%$ & $0.0 \%$ & $2.4 \%$ \\
\hline & & $\%$ of Total & $0.1 \%$ & $0.3 \%$ & $0.9 \%$ & $0.7 \%$ & $0.2 \%$ & $0.2 \%$ & $0.0 \%$ & $2.4 \%$ \\
\hline & \multirow[t]{4}{*}{ Unmet need for limiting } & Count & 0 & 1 & 2 & 7 & 9 & 11 & 6 & 36 \\
\hline & & $\%$ within Unmet need & $0.0 \%$ & $2.8 \%$ & $5.6 \%$ & $19.4 \%$ & $25.0 \%$ & $30.6 \%$ & $16.7 \%$ & $100.0 \%$ \\
\hline & & $\begin{array}{l}\text { \% within Age in 5-year } \\
\text { groups }\end{array}$ & $0.0 \%$ & $0.6 \%$ & $1.3 \%$ & $4.6 \%$ & $5.0 \%$ & $6.5 \%$ & $4.9 \%$ & $3.4 \%$ \\
\hline & & $\%$ of Total & $0.0 \%$ & $0.1 \%$ & $0.2 \%$ & $0.7 \%$ & $0.8 \%$ & $1.0 \%$ & $0.6 \%$ & $3.4 \%$ \\
\hline & \multirow[t]{4}{*}{ Using for spacing } & Count & 1 & 18 & 40 & 35 & 25 & 6 & 2 & 127 \\
\hline & & \% within Unmet need & $0.8 \%$ & $14.2 \%$ & $31.5 \%$ & $27.6 \%$ & $19.7 \%$ & $4.7 \%$ & $1.6 \%$ & $100.0 \%$ \\
\hline & & $\begin{array}{l}\text { \% within Age in 5-year } \\
\text { groups }\end{array}$ & $0.7 \%$ & $11.7 \%$ & $25.6 \%$ & $23.0 \%$ & $14.0 \%$ & $3.6 \%$ & $1.6 \%$ & $11.8 \%$ \\
\hline & & $\%$ of Total & $0.1 \%$ & $1.7 \%$ & $3.7 \%$ & $3.3 \%$ & $2.3 \%$ & $0.6 \%$ & $0.2 \%$ & $11.8 \%$ \\
\hline & \multirow[t]{4}{*}{ Using for limiting } & Count & 1 & 3 & 13 & 46 & 81 & 89 & 45 & 278 \\
\hline & & $\%$ within Unmet need & $0.4 \%$ & $1.1 \%$ & $4.7 \%$ & $16.5 \%$ & $29.1 \%$ & $32.0 \%$ & $16.2 \%$ & $100.0 \%$ \\
\hline & & $\begin{array}{l}\text { \% within Age in 5-year } \\
\text { groups }\end{array}$ & $0.7 \%$ & $1.9 \%$ & $8.3 \%$ & $30.3 \%$ & $45.3 \%$ & $53.0 \%$ & $36.9 \%$ & $25.9 \%$ \\
\hline & & $\%$ of Total & $0.1 \%$ & $0.3 \%$ & $1.2 \%$ & $4.3 \%$ & $7.5 \%$ & $8.3 \%$ & $4.2 \%$ & $25.9 \%$ \\
\hline & \multirow[t]{4}{*}{ Spacing failure } & Count & 0 & 1 & 4 & 1 & 0 & 0 & 0 & \\
\hline & & \% within Unmet need & $0.0 \%$ & $16.7 \%$ & $66.7 \%$ & $16.7 \%$ & $0.0 \%$ & $0.0 \%$ & $0.0 \%$ & $100.0 \%$ \\
\hline & & $\begin{array}{l}\text { \% within Age in 5-year } \\
\text { groups }\end{array}$ & $0.0 \%$ & $0.6 \%$ & $2.6 \%$ & $0.7 \%$ & $0.0 \%$ & $0.0 \%$ & $0.0 \%$ & $0.6 \%$ \\
\hline & & $\%$ of Total & $0.0 \%$ & $0.1 \%$ & $0.4 \%$ & $0.1 \%$ & $0.0 \%$ & $0.0 \%$ & $0.0 \%$ & $0.6 \%$ \\
\hline & \multirow[t]{4}{*}{ No unmet need } & Count & 0 & 20 & 40 & 24 & 23 & 12 & 1 & 120 \\
\hline & & \% within Unmet need & $0.0 \%$ & $16.7 \%$ & $33.3 \%$ & $20.0 \%$ & $19.2 \%$ & $10.0 \%$ & $0.8 \%$ & $100.0 \%$ \\
\hline & & $\begin{array}{l}\text { \% within Age in 5-year } \\
\text { groups }\end{array}$ & $0.0 \%$ & $13.0 \%$ & $25.6 \%$ & $15.8 \%$ & $12.8 \%$ & $7.1 \%$ & $0.8 \%$ & $11.2 \%$ \\
\hline & & $\%$ of Total & $0.0 \%$ & $1.9 \%$ & $3.7 \%$ & $2.2 \%$ & $2.1 \%$ & $1.1 \%$ & $0.1 \%$ & $11.2 \%$ \\
\hline & \multirow{4}{*}{$\begin{array}{l}\text { Not married and no sex in } \\
\text { last } 30 \text { days }\end{array}$} & Count & 1 & 10 & 2 & 5 & 8 & 7 & 3 & 36 \\
\hline & & $\%$ within Unmet need & $2.8 \%$ & $27.8 \%$ & $5.6 \%$ & $13.9 \%$ & $22.2 \%$ & $19.4 \%$ & $8.3 \%$ & $100.0 \%$ \\
\hline & & $\%$ within Age in 5-year & $0.7 \%$ & $6.5 \%$ & $1.3 \%$ & $3.3 \%$ & $4.5 \%$ & $4.2 \%$ & $2.5 \%$ & $3.4 \%$ \\
\hline & & $\%$ of Total & $0.1 \%$ & $0.9 \%$ & $0.2 \%$ & $0.5 \%$ & $0.7 \%$ & $0.7 \%$ & $0.3 \%$ & $3.4 \%$ \\
\hline & \multirow[t]{4}{*}{ Infecund, menopausal } & Count & 2 & 2 & 4 & 18 & 27 & 37 & 63 & 153 \\
\hline & & \% within Unmet need & $1.3 \%$ & $1.3 \%$ & $2.6 \%$ & $11.8 \%$ & $17.6 \%$ & $24.2 \%$ & $41.2 \%$ & $100.0 \%$ \\
\hline & & $\%$ within Age in 5-year & $1.4 \%$ & $1.3 \%$ & $2.6 \%$ & $11.8 \%$ & $15.1 \%$ & $22.0 \%$ & $51.6 \%$ & $14.3 \%$ \\
\hline & & $\%$ of Total & $0.2 \%$ & $0.2 \%$ & $0.4 \%$ & $1.7 \%$ & $2.5 \%$ & $3.4 \%$ & $5.9 \%$ & $14.3 \%$ \\
\hline & \multirow[t]{4}{*}{99} & Count & 0 & 0 & 0 & 0 & 0 & & & \\
\hline & & \% within Unmet need & $0.0 \%$ & $0.0 \%$ & $0.0 \%$ & $0.0 \%$ & $0.0 \%$ & $50.0 \%$ & $50.0 \%$ & $100.0 \%$ \\
\hline & & $\%$ within Age in 5-year & $0.0 \%$ & $0.0 \%$ & $0.0 \%$ & $0.0 \%$ & $0.0 \%$ & $0.6 \%$ & $0.8 \%$ & $0.2 \%$ \\
\hline & & $\%$ of Total & $0.0 \%$ & $0.0 \%$ & $0.0 \%$ & $0.0 \%$ & $0.0 \%$ & $0.1 \%$ & $0.1 \%$ & $0.2 \%$ \\
\hline \multirow[t]{4}{*}{ Total } & & Count & 142 & 154 & 156 & 152 & 179 & 168 & 122 & 1073 \\
\hline & & $\%$ within Unmet need & $13.2 \%$ & $14.4 \%$ & $14.5 \%$ & $14.2 \%$ & $16.7 \%$ & $15.7 \%$ & $11.4 \%$ & $100.0 \%$ \\
\hline & & $\begin{array}{l}\text { \% within Age in 5-year } \\
\text { groups }\end{array}$ & $100.0 \%$ & $100.0 \%$ & $100.0 \%$ & $100.0 \%$ & $100.0 \%$ & $100.0 \%$ & $100.0 \%$ & $100.0 \%$ \\
\hline & & $\%$ of Total & $13.2 \%$ & $14.4 \%$ & $14.5 \%$ & $14.2 \%$ & $16.7 \%$ & $15.7 \%$ & $11.4 \%$ & $1000 \%$ \\
\hline
\end{tabular}

Hasil uji chi-square menunjukkan $\mathrm{p}=0,00(\mathrm{p}<0,05)$, dengan demikian Ho ditolak dan Ha diterima yang artinya ada hubungan antara umur dengan kejadian Unmet Need di Provinsi Kepulauan Riau. Hal ini berarti umur mempengaruhi terjadinya unmet need. Tabel 06. menunjukkan bahwa responden pada rentang umur 25-29 tahun merupakan umur tertinggi berstatus Unmet Need for spasing sebanyak 38,5\%, dan pada unmed need for limiting tertinggi pada rentan umur 40-44 tahun sebanyak 30,6\%. Masih tingginya kejadian unmeet need pada sebaran kelompok umur 40-44 dikarenakan pada rentang umur tersebut wanita umur subur biasanya ingin membatasi kelahiran, namun tidak menggunakan alat/jenis kontrasepsi hal tersebut di sebabkan pada umur tersebut mendekati akhir umur reproduksinya, dikarenakan mereka mengira bahwa mereka tidak lagi memiliki resiko untuk hamil sehingga berhenti menggunakan kontrasepsi atau tidak menggunakan kontrasepsi jangka panjang. Oleh karena itu, unmet need untuk membatasi kelahiran dan resiko kehamilan yang tidak diinginkan menjadi lebih besar pada wanita yang berumur lebih matang. Selain itu Jika kehamilan ini terjadi di umur resiko tinggi yaitu diatas umur 35 tahun dapat memiliki resiko tinggi terhadap kesehatan ibu maupun janin bahkan dapat menyebabkan kematian. Hasil Kajian SDKI ini sejalan dengan kajian yang dilakukan oleh Ray \& Reza( 2018) tentang variabel umur, wanita dengan umur lebih dari 35 tahun memiliki kecenderungan 1,37 kali untuk berstatus unmet need dibandingkan wanita berumur di bawah atau sama dengan 35 tahun pada saat variabel lain konstan. Artinya semakin bertambah umur dari seorang wanita subur, kecenderungan untuk berstatus unmet need semakin besar jika variabel lain tetap. 


\section{KESIMPULAN}

1. Provinsi Kepulauan Riau memiliki tingkat unmet need KB sebesar 10,7 \%. Dengan sebaran data distribusi frekuensi unmet need KB di Provinsi Kepulauan Riau banyak ditemukan pada wanita usia subur dengan rentang umur 35-39 tahun sebanyak 16,7 \%, bertempat tinggal di wilayah perkotaan sebanyak $91,4 \%$, dengan tingkat pendidikan Menengah (Secondary) sebanyak 65,3\%, dan dengan tingkat ekonomi teratas (Richerts) sebanyak $37,4 \%$.

2. Terdapat hubungan yang bermakna antara umur, tingkat pendidikan, dan daerah tempat tinggal dengan kejadian unmet need Keluarga Berencana di Provinsi Kepulauan Riau Tahun 2017.

3. Tidak terdapat hubungan antara kuintil kekayaan dengan kejadian unmet need Keluarga Berencana di Provinsi Kepulauan Riau Tahun 2017

4. Responden rentang usia 15-49 tahun yang yang memiliki jenjang pendidikan primary/ dasar, secondary/menengah dan higher/tinggi memiliki peluang yang sama dalam meningkatkan resiko terjadinya unmet need di Provinsi Kepulauan Riau.

5. Responden pada rentang usia 15-49 tahun yang tinggal di perkotaan maupun di perdesaan memiliki kesempatan yang sama untuk meningkatkan resiko kejadian unmet need baik itu unmet need yang membatasi kelahiran maupun yang menjarangkan kehamilan.

6. Responden rentang usia 15-49 tahun yang yang memiliki kuintil kekayaan poorest/ terbawah, poorer/ menengah bawah, middle / menengah, richer / menengah atas, dan Richest / teratas memiliki peluang yang sama dalam meningkatkan resiko terjadinya unmet need di Provinsi Kepulauan Riau.

7. Responden yang tinggal di wilayah perkotaan mauapun perdesaan yang memiliki rentang umur 15-19 tahun dan 30-34 tahun memiliki peluang yang besar dalam meningkatkan resiko terjadinya unmet need di Provinsi Kepulauan Riau.

8. Responden yang tinggal di wilayah perkotaan mauapun perdesaan yang memiliki tingkat pendidikan dasar/primary memiliki peluang yang besar dalam meningkatkan resiko terjadinya unmet need di Provinsi Kepulauan Riau.

9. Responden yang tinggal di wilayah perkotaan mauapun perdesaan yang memiliki kuintil kekayaan poorest / terendah memiliki peluang yang besar dalam meningkatkan resiko terjadinya unmet need di Provinsi Kepulauan Riau.

10. Responden dengan tinkat pendidikan Primary, secondary dan higher dengan rentang usia 20-29 memiliki peluang yang besar dalam meningkatkan resiko terjadinya unmet need di Provinsi Kepulauan Riau.

11. Responden dengan tingkat pendidikan Primary, secondary dan higher yang tinggal di perkotaan maupun di pedesaan memiliki peluang yang besar dalam meningkatkan resiko terjadinya unmet need di Provinsi Kepulauan Riau

\section{DAFTAR PUSTAKA}

Anggraeni Anita T \& Susilaningrum Destri 2017. Pemodelan Dan Pemetaan Faktor Unmet Need Kb Di Jawa Timur Sebagai Perencanaan Mencegah Ledakan Penduduk Dengan Regresi Logistik Biner diakses dari http://matematika.fst.unair.ac.id/wpcontent/uploads/2019/03/31 April 2019

BKKBN. 2006. Buku Informasi Partisipasi Pria Dalam KB dan Kesehatan Reproduksi. BKKBN: Jakarta. $52 \mathrm{hlm}$.

BKKBN, 2009. Pedoman pelayanan KB dalam jaminan kesehatan masyarakat. Jakarta: $\mathrm{BKKBN}$ 
Desmiwati, Utami dan Endrinaldi. 2013. Faktor-Faktor yang Berhubunga dengan Unmet Need KB Pasca-Salin IUD Post-Placenta di Kamar Rawat PascaBersalin RSUP DR. M. Djaimil Periode Januari-Maret 2013. Jurnal Kesehatan. Fakultas Kedokteran Universitas Andalas. Padang. Hlm 158- 163. Diakses dari (http://www.ejournal.com/2014/10/faktor-faktor-yang-berhubungandengan22.htm pada Kamis, 2019)

Hartanto, Hanafi. 2007. Keluarga Berencana Dan Kontrasepsi. Pustaka Sinar Harapan: Jakarta

Hartanto, Hanafi. 2011. Keluarga Berencana Dan Kontrasepsi. Pustaka Sinar Harapan: Jakarta

Hamid, S. (2002). Faktor - faktor yang berhubungan dengan Unmet Need Keluarga Berencana (Analisis Data SDKI Tahun 1997). Tesis Program Pascasarjana Program Studi Ilmu Kesehatan Masyarakat, Universitas Indonesia : Jakarta diakses dari http:// lib.ui.ac.id/file?file $=$ pdf/abstrak-73198.pdf

Kementerian Kesehatan RI. 2013. Buletin Jendela Informasi Kesehatan. Kemenkes RI: Jakarta. 38 hlm.

Listyaningsih, Sumini dan Satiti. 2016. Unmet Need: Konsep yang Masih Perlu Diperdebatkan. Populasi Volume 24 Nomor 1 2016: 72-90. Fakultas Geografi Pusat Studi Kependudukan Dan Kebijakan. Universitas Gajah Mada. Yogyakarta. hlm 7290. Diakses dari (https://jurnal.ugm.ac.id/populasi/article/view/23696 pada April 2019)

Maria UR, (2018) Faktor Penyebab Terjadinya Unmet Need KB Pasangan Usia Subur (PUS) Di Kecamatan Labuhan Ratu Kota Bandar Lampung Tahun 2018 diakses dari http://digilib.unila.ac.id/54535/3/diakses tanggal 20 Januari 2019

Mantra, Ida Bagoes. 2003. Demografi Umum.Pustaka Pelajar Offset: Yogyakarta. $294 \mathrm{hlm}$

Notoatmodjo, S., 2010. Kesehatan Masyarakat Ilmu dan Seni. Edisi Revisi. Jakarta : Rineka Cipta 